\title{
Preparation, Diagnosis, Biological Activity, and Theoretical Studies of Some Mixed Drug Complexes
}

\author{
Bayader F. Abbas, Barakat A. F. Kamel (D), and Wessal M. Khamais \\ Department of Chemistry, College of Science, Al-Mustansiriyah University, Baghdad, Iraq \\ Correspondence should be addressed to Barakat A. F. Kamel; baraka19832012@yahoo.com
}

Received 11 February 2019; Accepted 28 March 2019; Published 8 May 2019

Academic Editor: Chih-Ching Lin

Copyright (C) 2019 Bayader F. Abbas et al. Thisis an open access article distributed under the Creative Commons Attribution License, which permits unrestricted use, distribution, and reproduction in any medium, provided the original work is properly cited.

\begin{abstract}
This paper includes synthesis and characterization of mixed ligand complexes derived from mefenamic acid and metformin using transition metal ions such as $\mathrm{Co}(\mathrm{II})$ and $\mathrm{Cu}(\mathrm{II})$. These complexes have been characterized by magnetic susceptibility, molar conductance, TG analyses, and spectral techniques such as FTIR and UV spectra. The theoretical study of the ligands and their complexes using semiempirical (PM6) method was used to measure IR and UV spectroscopy, HOMO-LUMO categories of the ligands. These synthesized complexes are also studied for their biological activities. The studies made on these complexes proposed a six octahedral geometry.
\end{abstract}

\section{Introduction}

Mefenamic acid [ $\left.\mathrm{L}_{1}\right]$ 2-[(2,3- dimethylphenyl)amino]benzoic acid], an anthranilic acid derivative, which is widely used to relieve mild to moderate pain [1], demonstrates nonsteroidal anti-inflammatory, antipyretic, and analgesic activity $[2,3]$. Metformin $\left[\mathrm{L}_{2}\right]$ has two amino groups that have an excellent ability to coordinate with many transitional chain elements, thus giving highly colored clonal complexes, especially copper (II), nickel (II), and cobalt (II), because these metal ion complexes can be measured spectrally [4-6]. Metformin is a low-cost antioxidant. Metformin tablets also help reduce body weight or at least weight stability. Most tablets are used to treat high blood sugar that causes increased body weight [7]. Metformin hydrochloride is freely soluble in water and practically soluble in acetone, ether, and chloroform, and $\mathrm{pH}$ of a $1 \%$ water solution of metformin hydrochloride is 6.68 [8]. All the synthesized mixed ligand complexes $(0.5 \mathrm{mg} / \mathrm{mL})$ were screened for their antibacterial activities against five bacteria (Staphylococcus aureus, Escherichia coli, Streptococcus sp., Candida albicans, and Pseudomonas aeruginosa) by agar well diffusion assay method [9] using DMSO as control. The standard Tetracycline $(0.05 \mathrm{mg} / \mathrm{mL})$ antibiotic was used as an antibacterial agent. The inoculated plates were incubated at $30^{\circ} \mathrm{C}$ and $37^{\circ} \mathrm{C}$ temperature for 48 hours, and inhibition zone was measured in $\mathrm{mm}$. Theoretically the PM6 semiempirical method was used to carry out the calculations for the ligands and their complexes after being constructed and was used to analyze the structural and electronic parameters; the structures were fully optimized and vibrational analysis was carried out to verify that the optimized geometries corresponded to minimum global energy [10].

\section{Materials and Methods}

2.1. Materials. All the chemicals were supplied from Samarra Laboratories for Drugs Industry (IRAQ), BDH, and Fluka; these materials were used without further purification.

2.2. Instruments. Atomic absorption using Shimadzu model 6809, FTIR-8300 Shimadzu spectrophotometer, in the frequency range of $4000-400 \mathrm{~cm}^{-1}$, UV-visible spectrophotometer using Varian model, and conductivity meter using Philips. The melting points were recorded in Coslab melting point apparatus. The magnetic susceptibility of the solid complexes was obtained at room temperature using Magnetic Susceptibility Balance Johnson Matthey. Elemental analysis (EA) was carried out using elemental analyzer.

\subsection{Methods}

2.3.1. Synthesis of Mixed Drug Complexes. Synthesis of mixed drug complexes was carried out using template method. A 


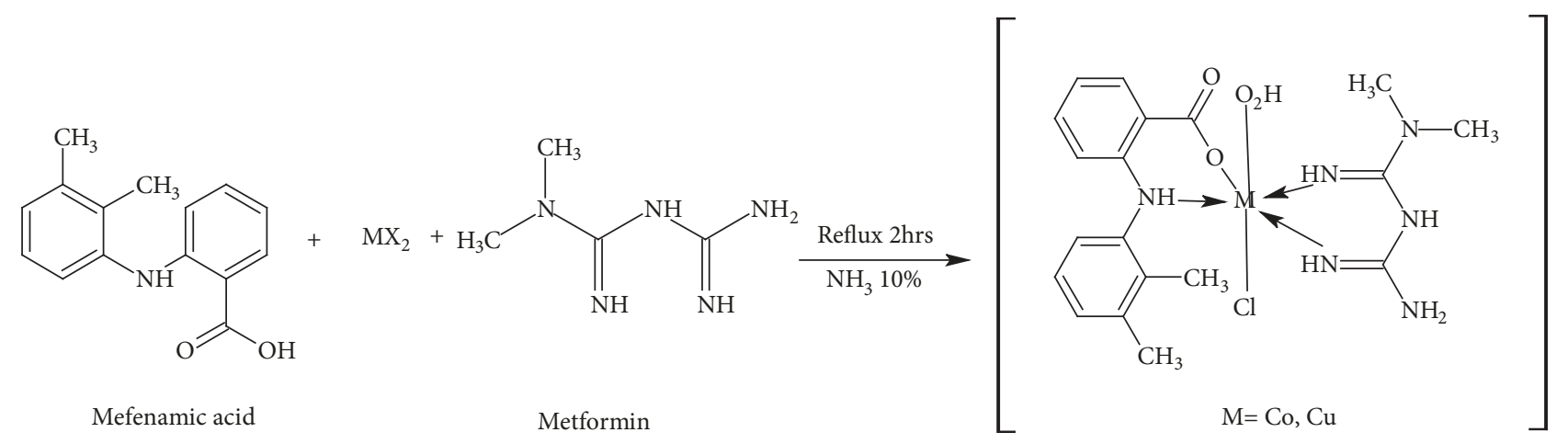

Scheme 1: Synthesis of mixed drug complexes.

TABLE 1: Physicochemical properties of ligands and synthesized complexes.

\begin{tabular}{|c|c|c|c|c|c|c|}
\hline Comp. & M.Wt & Color & Melting Point $\left({ }^{\circ} \mathrm{C}\right)$ & Yield(\%) & Molar Conductance $\left(\mathrm{ohm}^{-1} \cdot \mathrm{mol}^{-1} \cdot \mathrm{cm}^{2}\right)$ & B.M $(\mu)$ \\
\hline $\mathrm{C} 15 \mathrm{H} 15 \mathrm{NO} 2\left[\mathrm{~L}_{1}\right]$ & 241 & White & $230-231$ & ----- & ----- & --- \\
\hline C4H11N5 $\left[\mathrm{L}_{2}\right]$ & 129 & White & $221-222$ & $-\ldots$ & $-\ldots$ & $-\ldots$ \\
\hline$\left[\mathrm{Co}\left(\mathrm{L}_{1}\right)\left(\mathrm{L}_{2}\right) \mathrm{H}_{2} \mathrm{OCl}\right]$ & 481 & Violet & $>300$ & 71 & 18 & 4.7 \\
\hline$\left[\mathrm{Cu}\left(\mathrm{L}_{1}\right)\left(\mathrm{L}_{2}\right) \mathrm{H}_{2} \mathrm{OCl}\right]$ & 486 & Pink & $>300$ & 83 & 11 & 1.65 \\
\hline
\end{tabular}

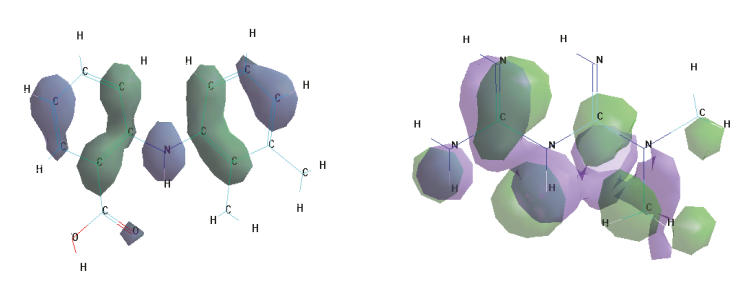

FIGURE 1: HOMO-LUMO categories of the ligands (mefenamic acid and metformin).

hot ethanolic solution $(10 \mathrm{ml})$ of respective transition metal salts $(1 \mathrm{mmol})$ was mixed with a hot solution $(1 \mathrm{mmol})$ of mefenamic acid and metformin ( $1 \mathrm{mmol})$. Few drops of dil. NH3 10\% were added to the mixture. The resulting mixture was then left under reflux for 2 hours. After refluxing for $2 \mathrm{hrs}$ appropriate complexes were precipitated out on cooling the reaction mixture. Those were then filtered, washed with ethanol, and washed using cold water $[11,12]$. The synthesized complexes were obtained in $65-72 \%$ yield. Scheme 1 shows the mechanism for synthesis of the mixed drug complexes.

\section{Results and Discussion}

3.1. Physicochemical Properties of Ligands and Complexes. All the synthesized complexes were thermally stable and colored. The magnetic moments of the solid complexes were measured by Farady's method at $300 \mathrm{~K}$ and the values observed for copper(II) complex were 1.69-1.78 BM which fall in one of the expected electrons for $\mathrm{d}^{9}$ configurations [13]. However, the increased magnetic susceptibility of cobalt(II) complexes in the 4.75-4.85 BM region supports the octahedral geometry around $\mathrm{Co}$ (II) ion due to orbital contribution. Table 1 shows the physicochemical properties of these synthesized complexes.

Figure 1 shows the HOMO-LUMO categories for the ligands according to semiempirical method (PM6).

3.2. IR Spectra of Ligands and Complexes. The ligand (metformin) shows three sharp absorption bundles at regions $3373 \mathrm{~cm}^{-1}$ and $3159-3298 \mathrm{~cm}^{-1}$ assigned to groups $\mathrm{NH}$ and $\mathrm{NH}_{2}$, respectively; peak $\mathrm{C}=\mathrm{N}$ appears at $1583-1626 \mathrm{~cm}^{-1}$ and $1276-1419 \mathrm{~cm}^{-1}$ assigned to $\mathrm{C}=\mathrm{N}$; and $\mathrm{N}-\mathrm{N}$ appears at $937 \mathrm{~cm}^{-1}$. Mefenamic acid has $\mathrm{N}-\mathrm{H}$ band appearing at $3340 \mathrm{~cm}^{-1}$. The vibrational spectrum of the synthesized complexes showed the difference in the severity of the packs $\mathrm{C}$ $=\mathrm{N}$ and $\mathrm{NH}$, respectively, having clearer deviations than in the free ligand. This is evidence of the participation of the nitrogen atom in the uniformity of the metal ion. This is shown by resonance and the change in the intensity of the group $\mathrm{C}=\mathrm{N}$ towards the red displacement in the complex was recorded in the free ligand $\left(1583-1626 \mathrm{~cm}^{-1}\right)\left(1612-1629 \mathrm{~cm}^{-1}\right)$ in the metal complex due to consistency and the formation of the motor stabilized system [10]. The presence of $812 \mathrm{~cm}^{-1}$ refers to the frequency of $\mathrm{M}-\mathrm{N}=\mathrm{C}$ group and the new band in the range of $(486-449) \mathrm{cm}^{-1}$ in the spectra of products was assigned to M-O group [14] as in Figures 2 and 3. Table 2 shows the IR spectra of ligands and their complexes experimentally and theoretically using semiempirical (PM6) method.

3.3. UV-Visible Spectra. The electronic spectra of the ligands $\mathrm{L}_{1}, \mathrm{~L}_{2}$ and their metal complexes were measured in ethanol and DMSO solutions. The mefenamic acid and metformin base ligand $\mathrm{L}_{1}, \mathrm{~L}_{2}$ displayed absorption around and in the $220 \mathrm{~nm}$ region assigned to the $\pi \longrightarrow \pi *$ transition that is unaffected in the formation of complexes. The peaks around 


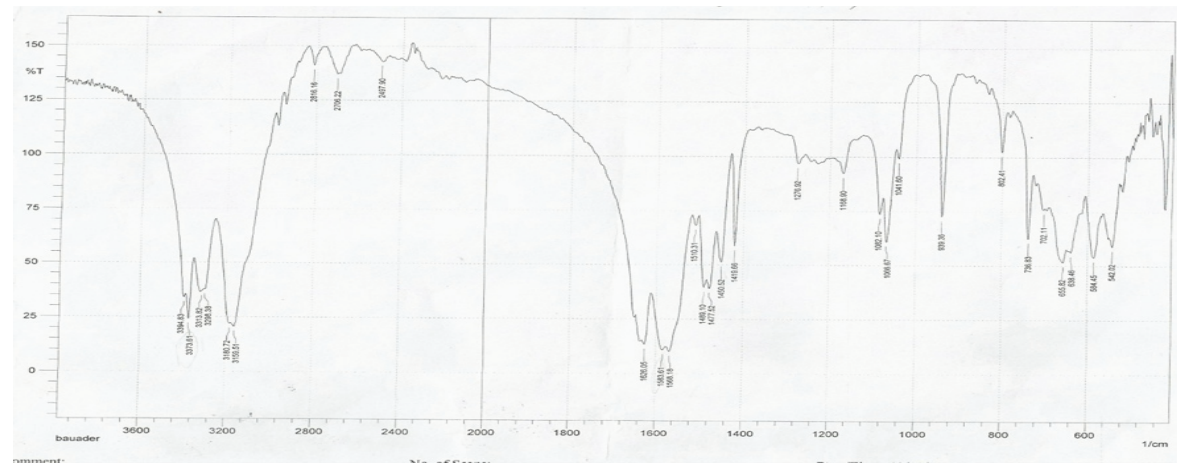

FIgURE 2: The IR spectra of the ligand metformin $\left(\mathrm{L}_{2}\right)$.

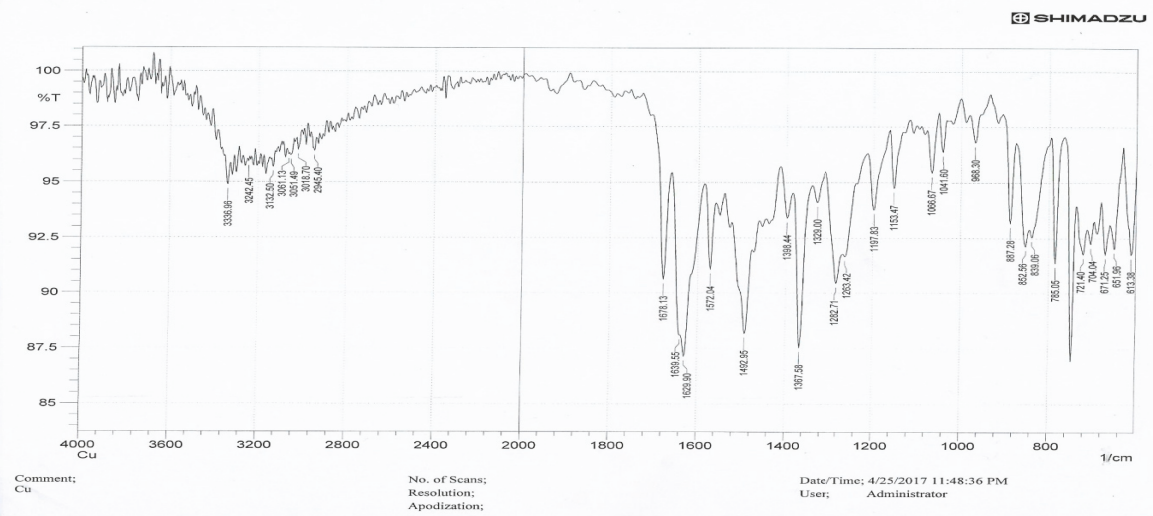

FIgURE 3: The IR spectra of the complex [Cu(L1)(L2) $\left.\mathrm{H}_{2} \mathrm{OCl}\right]$.

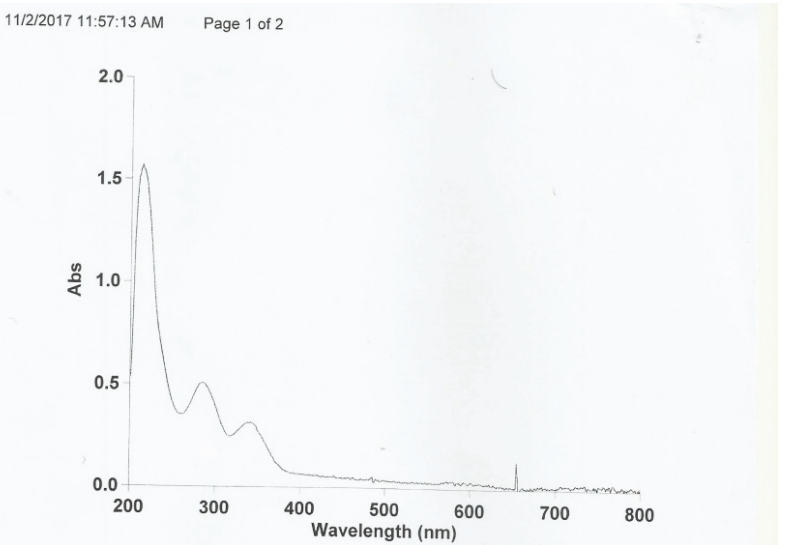

Figure 4: UV-Vis spectra of the complex $\mathrm{Co}\left(\mathrm{L}_{1}\right)\left(\mathrm{L}_{2}\right) \mathrm{H}_{2} \mathrm{OCl}$.

290 and $350 \mathrm{~nm}$ are assigned to $\mathrm{n} \longrightarrow \pi *$ transitions of $(-\mathrm{C}=\mathrm{N}-,-\mathrm{C}=\mathrm{C}, \mathrm{C}=\mathrm{O})$ groups and intraligand charge transfer [15]. Transition metal complexes showed the following $d \longrightarrow$ $d$ transition. Two bands observed for $\mathrm{Co}^{+2}$ complex go to the transitions ${ }^{4} \mathrm{~T}_{1} \mathrm{~g} \longrightarrow{ }^{4} \mathrm{~T}_{2} \mathrm{~g}(\mathrm{~F})$ and ${ }^{4} \mathrm{~T}_{1} \mathrm{~g}(\mathrm{~F}) \longrightarrow{ }^{4} \mathrm{~T}_{1} \mathrm{~g}(\mathrm{P})$, respectively, suggesting high spin octahedral geometry $\left(t_{2} g^{5} e^{2}\right)$ [16]. For $\mathrm{Cu}^{+2}$ complex, only two broad bands were recorded for the first at $16149 \mathrm{~cm}^{-1}$ and shoulder for the second at $27027 \mathrm{~cm}^{-1}$, while the third one did not appear due to its position at infrared region suggesting a distorted octahedral geometry [17]. Figure 4 and Table 3 show the UV-Vis spectra of the complex $\left[\mathrm{Co}\left(\mathrm{L}_{1}\right)\left(\mathrm{L}_{2}\right) \mathrm{H}_{2} \mathrm{OCl}\right]$.

3.4. Thermogravimetric Analysis (TGA). Thermogravimetric analyses (weight changes) were performed in the temperature up to $600^{\circ} \mathrm{C}$ under argon atmosphere at the heating rate $20 \mathrm{C} / \mathrm{min}$. The thermogram of $\mathrm{Co}^{\mathrm{II}}, \mathrm{Cu}^{\mathrm{II}}$ complexes recorded three stages of weight loss as shown in Figures 5 and 6 . The first one showed the initial weight loss in the temperature around 347, $335 \mathrm{C}$ probably be due to the loss in the coordinated big weight due to the decomposition of organic constituents of complexes molecule. The metal oxide could represent the final residue with attaining a constant weight [18]. Furthermore the DSC analysis of nickel (II) complexes showed the stability of complexes in inert helium gas and the peaks, being exothermic, were very important to estimate some thermodynamic terms like enthalpy, entropy, and Gibbs-Free energy as shown in Figures 5 and 6.

3.5. Biological Activity. Biological activities of these complexes against different bacterial isolates were studied. The biological activities of the test compounds were evaluated by the well diffusion method against E. coli, Staphylococcus 
TABLE 2: Experimental and theoretical IR spectrum bands of ligands and their complexes.

\begin{tabular}{|c|c|c|c|c|}
\hline Comp. & $v(\mathrm{~N}-\mathrm{H})$ & $v(\mathrm{C}=\mathrm{O})$ & $v(\mathrm{COO})$ & $v(\mathrm{M}-\mathrm{O})$ \\
\hline $\mathrm{C} 15 \mathrm{H} 15 \mathrm{NO} 2$ [I ] & 3340 & 1730 & $1673-1422$ & \\
\hline CIJHIJNUL $\left[\mathrm{L}_{1}\right]$ & $(3332)_{\mathrm{P}}$ & $(1721)_{\mathrm{P}}$ & $(1676-1396)_{\mathrm{P}}$ & \\
\hline C4H11N5 $\left[\mathrm{L}_{2}\right]$ & $\begin{array}{c}3373 \\
(3388)_{\mathrm{P}}\end{array}$ & - - & $-\ldots$ & $-\cdots$ \\
\hline$\left[\mathrm{Co}\left(\mathrm{L}_{1}\right)\left(\mathrm{L}_{2}\right) \mathrm{H}_{2} \mathrm{OCl}\right]$ & $\begin{array}{c}3327 \\
(3315)_{\mathrm{P}}\end{array}$ & & $\begin{array}{c}1678-1492 \\
(1672-1494)_{\mathrm{P}}\end{array}$ & $\begin{array}{c}486 \\
(490)_{\mathrm{P}}\end{array}$ \\
\hline$\left[\mathrm{Cu}\left(\mathrm{L}_{1}\right)\left(\mathrm{L}_{2}\right) \mathrm{H}_{2} \mathrm{OCl}\right]$ & $\begin{array}{c}3336 \\
(3334)_{\mathrm{P}}\end{array}$ & & $\begin{array}{c}1614-1462 \\
(1615-1458)_{\mathrm{P}}\end{array}$ & $\begin{array}{c}491 \\
(499)_{\mathrm{P}}\end{array}$ \\
\hline
\end{tabular}

${ }^{*}$ P: semiempirical (PM6) method.

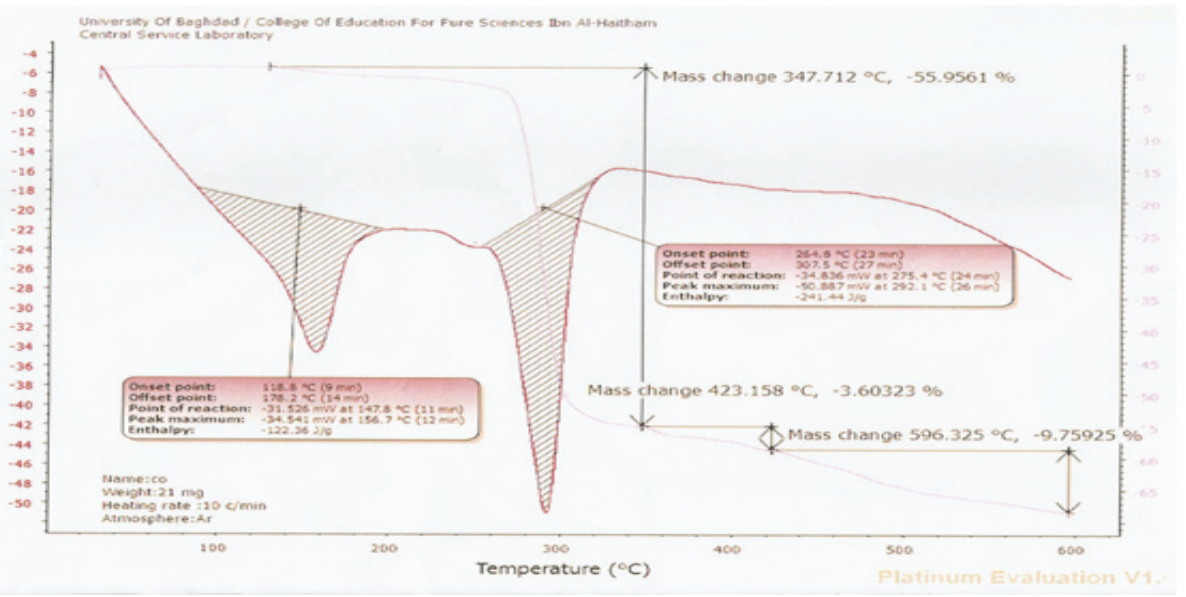

Figure 5: TG/DTG and DSC thermogram of $\left[\mathrm{Co}\left(\mathrm{L}^{1}\right)\left(\mathrm{L}^{2}\right) \mathrm{H}_{2} \mathrm{OCl}\right]$ in argon atmosphere.

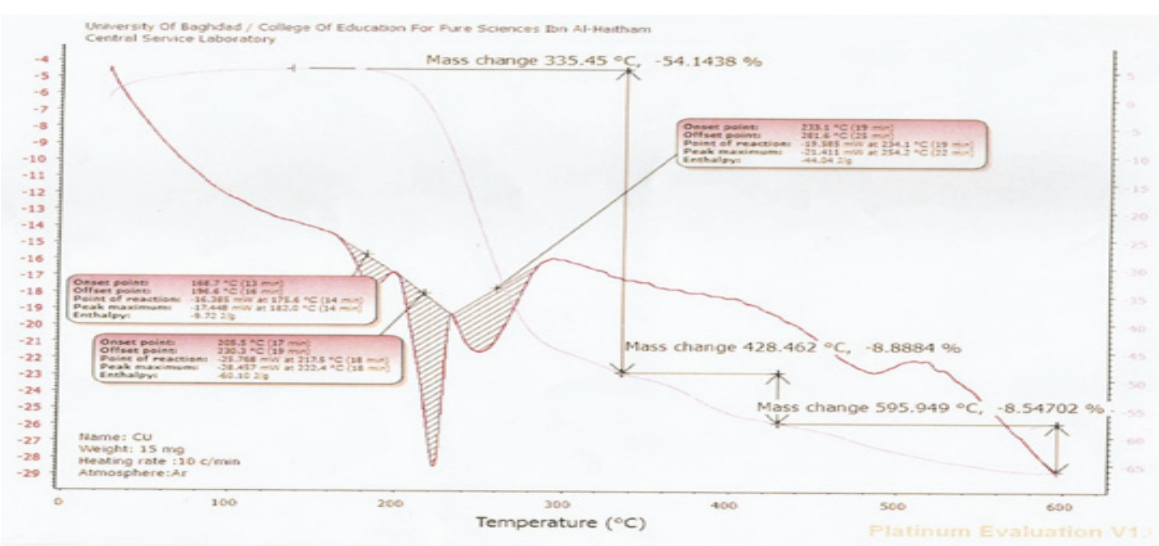

FIGURE 6: TG/DTG and DSC thermogram of $\left[\mathrm{Cu}\left(\mathrm{L}^{1}\right)\left(\mathrm{L}^{2}\right) \mathrm{H}_{2} \mathrm{OCl}\right]$ in argon atmosphere biological activity.

aureus, Streptococcus mutans, Pseudomonas aeruginosa, and Candida albicans (fungus). In this method pure isolate of $24 \mathrm{hr}$ growth was cultured in Muller-Hinton Agar plate $(\mathrm{Hi}$ Media, Mumbai, India) by using sterile swab so as to achieve a confluent growth. The plates were allowed to dry and a sterile cork borer of diameter $8.0 \mathrm{~mm}$ was used to bore four wells in each agar plates. A $10 \mu \mathrm{L}$ volume of each complex was applied by micropipette in the wells into MullerHinton Agar plate. Distilled water served as control. The plates were allowed to stand for 1 h or more for diffusion to take place and then incubated at $37^{\circ} \mathrm{C}$ for $24 \mathrm{hrs}$. The zone of inhibition was recorded [19]. Several researches have shown that coordination of organic compounds to a metallic element causes significant changes in the biological activity of both the organic ligand and the metal. The ligands showed antimicrobial activity against both kinds of bacteria. The complex Co-ligand 1/ligand 2/DMSO has the highest inhibition zone among the others. The complex $\mathrm{Cu}$ - ligand 1/ligand 2/DMSO also showed significant antimicrobial activity effect, which does not have antibacterial activity against 


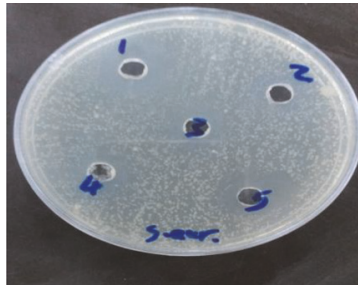

Staphylococcus aureus

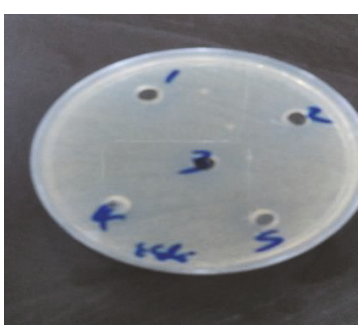

E. coli

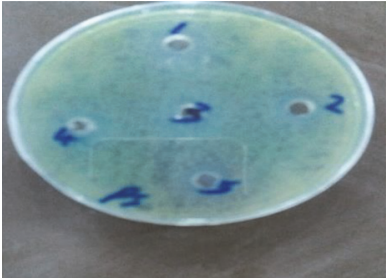

Pseudomonas aeruginosa

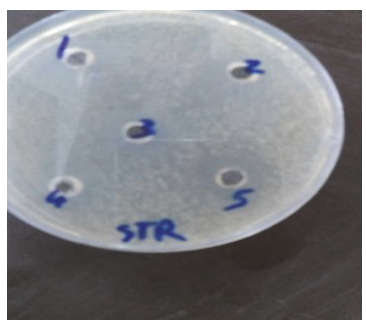

Streptococcus sp

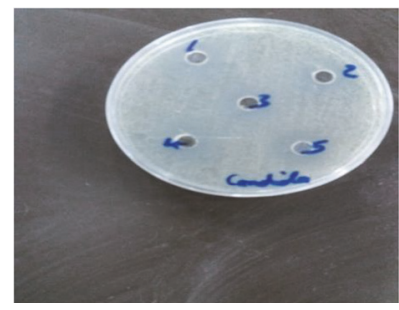

Candida albicans

FIGURE 7: Effect of ligands and their complexes in the inhibition of different kinds of bacteria.

TABLE 3: Experimental and theoretical UV-Vis spectrum bands of ligands and their complexes.

\begin{tabular}{lcc}
\hline Compounds & Bands $(\mathrm{nm})$ & Geometry \\
\hline $\mathrm{C} 15 \mathrm{H} 15 \mathrm{NO} 2\left[\mathrm{~L}_{1}\right]$ & $324-247$ & \\
& $(323-237)_{\mathrm{P}}$ & \\
$\mathrm{C} 4 \mathrm{H} 11 \mathrm{~N} 5\left[\mathrm{~L}_{2}\right]$ & $237-266$ & - \\
& $(222-265)_{\mathrm{P}}$ & Octahedral \\
{$\left[\mathrm{Co}\left(\mathrm{L}_{1}\right)\left(\mathrm{L}_{2}\right) \mathrm{H}_{2} \mathrm{OCl}\right]$} & $610-489-341$ & \\
& $(596-484-337)_{\mathrm{P}}$ & Octahedral \\
{$\left[\mathrm{Cu}\left(\mathrm{L}_{1}\right)\left(\mathrm{L}_{2}\right) \mathrm{H}_{2} \mathrm{OCl}\right]$} & $580-370-290$ & $(670-365-296)_{\mathrm{P}}$ \\
\hline
\end{tabular}

${ }^{*}$ P: semiempirical (PM6) method.

Staphylococcus aureus and Streptococcus mutans shown in the higher inhibition zone of metal complexes than those of the ligands, which can be explained on the basis of Overtone's concept and chelation theory. On chelation, the polarity of the metal ion will be reduced to a greater extent due to the overlap of the ligand orbital and partial sharing of the positive charge of the metal ion with donor groups. The weak antibacterial activity for $\mathrm{Cu}$-ligand/DMSO and Co-ligand/DMSO against gram negative bacteria was ascribed to the presence of an outer membrane, which poses hydrophilic polysaccharides chains as a barrier to these complexes. Cobalt is not generally considered to be a very toxic element [20, 21]. A large number of reports on the antibacterial properties of cobalt complexes have shown $\mathrm{Co}(\mathrm{II})$ complexes to be the most studied probably due to their aqueous stability, accessibility, and ease of synthesis. However, only a small number of cobalt (III) complexes have biochemical roles. Vitamin B12 is a cobaloxime, a cobalt complex having a glyoxime ligand, and is one of the unusual examples of a naturally occurring organometallic complex, i.e., possessing a metal carbon bond [22]. Figure 7 and Table 4 show the effect of ligands and their complexes on different kinds of bacteria.

\section{Conclusions}

We concluded in this work that the synthesized complexes, prepared from mixed drugs (mefenamic acid and metformin), had octahedral geometric shapes; the biological 
TABLE 4: Biological activities of the ligands and their complexes against different bacterial isolates.

\begin{tabular}{|c|c|c|c|c|c|c|}
\hline Bacterial isolates & DMSO & Ligand $1 \backslash \mathrm{DMSO}$ & Ligand 2/DMSO & $\begin{array}{c}\text { Ligand } \\
1+2 / \mathrm{DMSO}\end{array}$ & $\begin{array}{c}\text { Co ligand } \\
1+2 / \mathrm{DMSO}\end{array}$ & $\begin{array}{c}\mathrm{Cu} \text {-ligand } \\
1+2 / \mathrm{DMSO}\end{array}$ \\
\hline Staphylococcus aureus & - & 21 & 15 & 14 & 14 & 15 \\
\hline Pseudomonas aeruginosa & - & 14 & - & - & 13 & 10 \\
\hline E. coli & - & 15 & - & - & 15 & 12 \\
\hline Streptococcus sp. & - & 15 & - & 12 & 15 & 11 \\
\hline Candida albicans & - & 14 & 14 & 12 & 16 & 13 \\
\hline
\end{tabular}

activity of these drugs against different kinds of bacteria increased after being mixed with $\mathrm{Cu}(\mathrm{II})$ and $\mathrm{Co}(\mathrm{II})$. We concluded that there is a great convergence between experimental and theoretical results using semiempirical (PM6) method.

\section{Data Availability}

The data used to support the findings of this study are available from the corresponding author upon request.

\section{Conflicts of Interest}

The authors declare that there are no conflicts of interest.

\section{Acknowledgments}

This work was performed in the Laboratories of the Chemistry and Biology Departments in Al-Mustansiriyah University.

\section{References}

[1] D. Wisher, "Martindale: the complete drug reference 37th ed," Journal of the Medical Library Association, vol. 100, no. 1, pp. 7576, 2012.

[2] C. V. Winder, J. Wax, B. Serrano, E. M. Jones, and M. L. McPhee, "Anti-inflammatory and antipyretic properties of $\mathrm{N}$ ( $\alpha, \alpha, \alpha$-Trifluoro-m-tolyl) anthranilic acid (CI-440; flufenamic acid)," Journal of Pharmacology and Experimental Therapeutics, vol. 138, no. 1, pp. 13-405, 1962.

[3] M. O. Goodarzi and M. Bryer-Ash, "Metformin revisited: reevaluation of its properties and role in the pharmacopoeia of modern antidiabetic agents," Diabetes, Obesity and Metabolism, vol. 7, no. 6, pp. 654-665, 2005.

[4] H. M. Nafea, Spectroscopic Studies and Analysis of Complexes via the Reaction of Selected Ligands with Some Metal Ions [M. Thesis], University of Baghdad, Iraq, 2011.

[5] K. R. Nalamolu and M. Annapurna, "Copper and nickel complexes of metformin synthesis, characterization and pharmacodynamic evaluation," Research Papers, vol. 3, pp. 43-46, 2007.

[6] F. Bentefrit, G. Morgant, B. Viossat et al., "Synthesis and antitumor activity of the metformin platinum (IV) complex. Crystal structure of the tetrachloro(metformin)platinum (IV) dimethylsulfoxide solvate," Journal of Inorganic Biochemistry, vol. 68 , no. 1, pp. 53-59, 1997.

[7] H. A. Abdulgane, B. A. Kamel, F. W. Askar, and H. H. Mohammed, "Synthesis and theoretical study of new quinazolinone derivatives containing various heterocyclic moieties,"
International Research Journal of Pharmacy, vol. 9, no. 5, pp. 7580, 2018.

[8] L. B. A. Rojas and M. B. Gomes, "Metformin: an old but still the best treatment for type 2 diabetes," Diabetology \& Metabolic Syndrome, vol. 5, no. 6, pp. 1-15, 2013.

[9] V. Shailendrasingh, F. Mazahar, and S. D. Naikwade, "Thermodynamic studies of transition metal complexes with Metformin Hydrochloride drug in 20\% (v/v) ethanol-water mixture," Der Chemica Sinica, vol. 3, no. 6, pp. 1406-1409, 2012.

[10] K. Nakamato, Infra-Red Spectral Inorganic and Coordination Compound, 4th edition, 1986.

[11] D. S. Wankhede, N. D. Mandawat, and A. H. Qureshi, "Mixed ligand complexes derived from 4-(Benzene Azo) salicyladehyde and 2-amino -4-nitrophenol using transition metal ions," Journal of Current Chemical Pharmaceutical Sciences, vol. 4, no. 3, pp. 135-141, 2014.

[12] R. Kumari and K. K. Jha, "Synthesis and characterization of mixed ligand complexes of transition," International Research Vision, vol. 3, no. 2, pp. 19-23, 2017.

[13] K. Prasad, L. Kumar, S. C. Shekar et al., "Oxovanadium complexes with bidentate N, O ligands: synthesis,characterization, DNA binding, nuclease activity and antimicrobial studies," Chemical Sciences Journal, vol. 2, pp. 1-10, 2011.

[14] C. Deleuze-Masquefa, G. Moarbess, S. Khier et al., "New imidazo[1,2-a]quinoxaline derivatives: Synthesis and in vitro activity against human melanoma," European Journal of Medicinal Chemistry, vol. 44, no. 9, pp. 3406-3411, 2009.

[15] C. Krushna, C. Mohapatra, and K. C. Dash, "4-, 5- and 6coordinate complexes of copper(II) with substituted imidazoles," Journal of Inorganic and Nuclear Chemistry, vol. 39, no. 7, pp. 1253-1258, 1977.

[16] T. Sarojini and A. Ramachandraiah, "Synthesis and characterisation of copper(II), cobalt(II), nickel(II), iron(II) and oxovanadium(IV) chelates of a new pair of Schiff base ligands derived from 1, 3-bis(aminomethyl)cyclohexane," Indian Journal of Chemistry - Section A Inorganic, Physical, Theoretical and Analytical Chemistry, vol. 35, no. 11, pp. 940-945, 1996.

[17] C. J. Dhanaraj and J. Johnson, "Studies on some quinoxaline metal complexes: synthesis, spectral characterization, electrochemical, antimicrobial, DNA interaction, molecular docking, and DFT studies," Inorganic and Nano-Metal Chemistry, vol. 47, no. 9, pp. 1348-1358, 2017.

[18] J. Lv, T. Liu, S. Cai, X. Wang, L. Liu, and Y. Wang, "Synthesis, structure and biological activity of cobalt(II) and copper(II) complexes of valine-derived schiff bases," Journal of Inorganic Biochemistry, vol. 100, no. 11, pp. 1888-1896, 2006.

[19] R. Shazia, I. Muhammad, N. Anwar, A. Haji, and A. Amin, "Transition metal complexes as potential therapeutic agents," Biotechnology and Molecular Biology Reviews, vol. 5, no. 2, pp. 38-45, 2010. 
[20] M. O. Agwara, P. T. Ndifon, N. B. Ndosiri, A. G. Paboudam, D. M. Yufanyi, and A. Mohamadou, "Synthesis, characterisation and antimicrobial activities of cobalt(II), copper(II) and zinc(II) mixed-ligand complexes containing 1,10-phenanthroline and 2,2' -bipyridine," Bulletin of the Chemical Society of Ethiopia, vol. 24, no. 3, pp. 383-389, 2010.

[21] A. Stǎnilă, C. Braicu, S. Stănilă, and R. M. Pop, "Antibacterial activity of copper and cobalt amino acids complexes," Notulae Botanicae Horti Agrobotanici Cluj-Napoca, vol. 39, no. 2, pp. 124-129, 2011.

[22] M. Alias, H. Kassum, and C. Shakir, "Synthesis, physical characterization and biological evaluation of Schiff base M(II) complexes," Journal of the Association of Arab Universities for Basic and Applied Sciences, vol. 15, no. 1, pp. 28-34, 2014. 

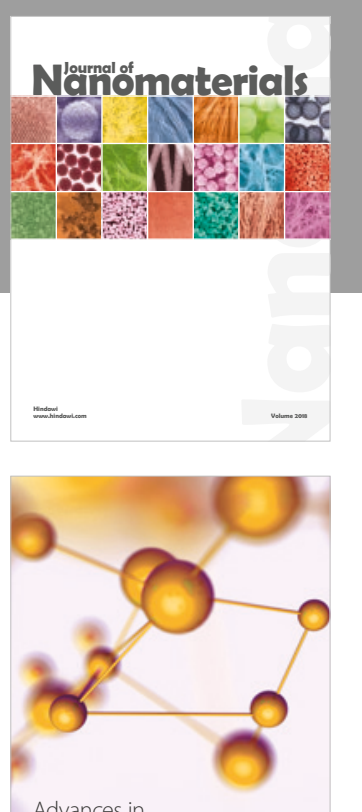

Physical Chemistry
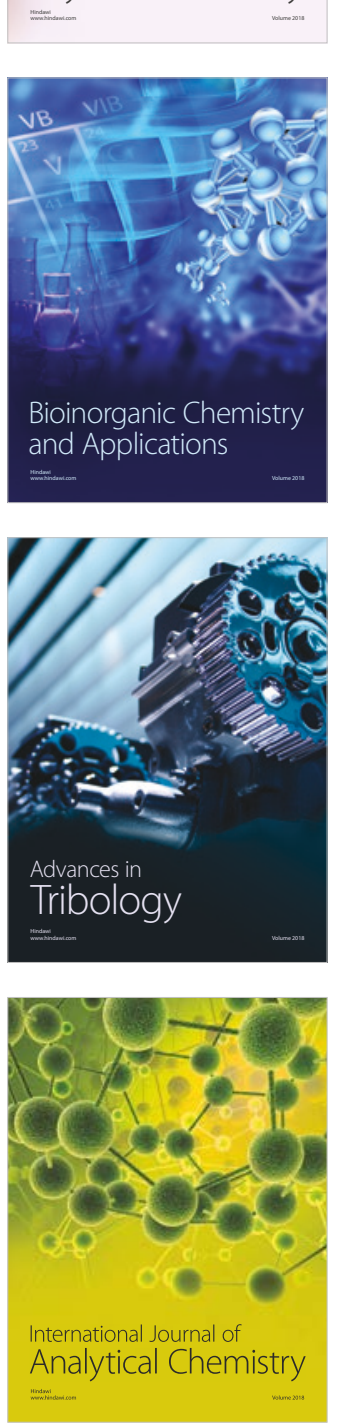

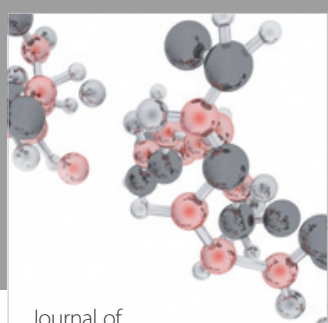

Analytical Methods

in Chemistry

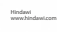

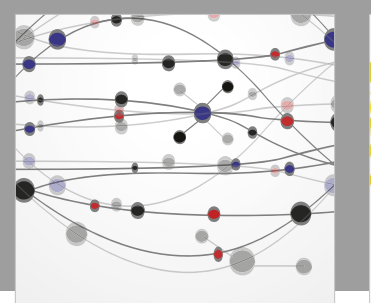

The Scientific World Journal

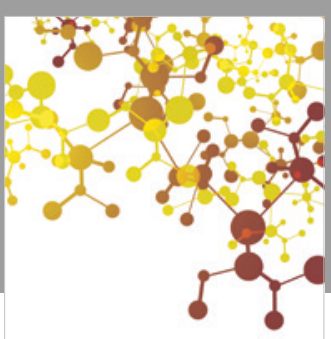

Journal of

Applied Chemistry
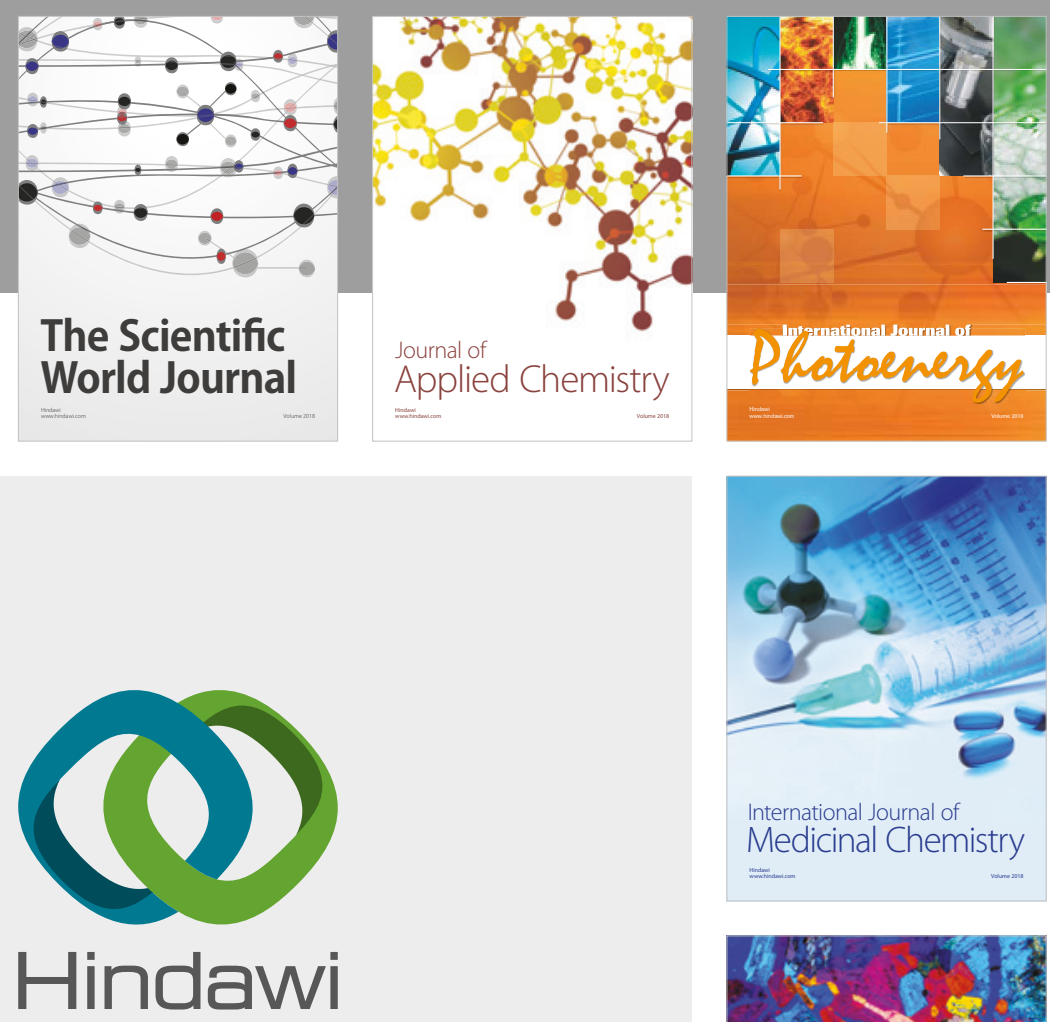

Submit your manuscripts at

www.hindawi.com
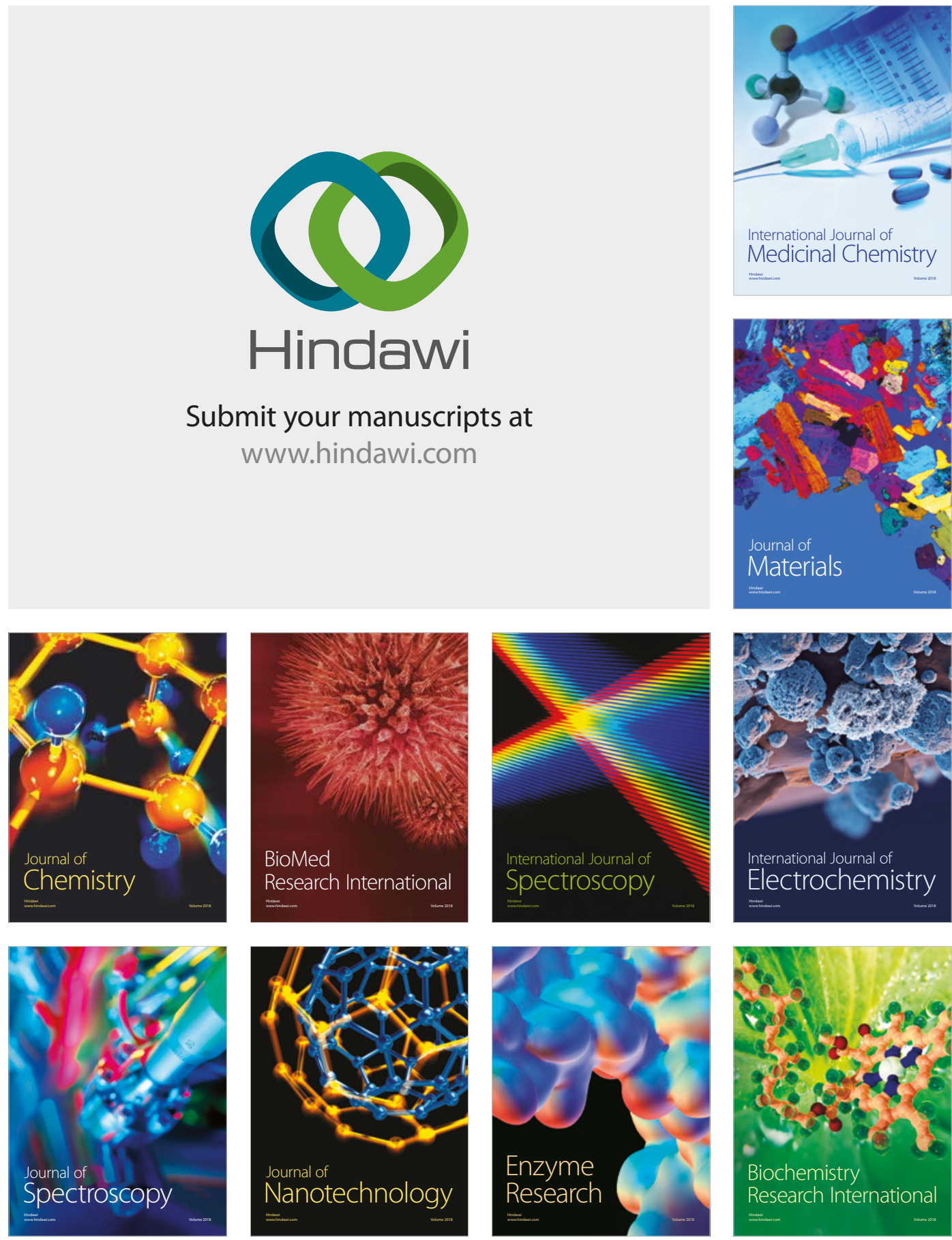
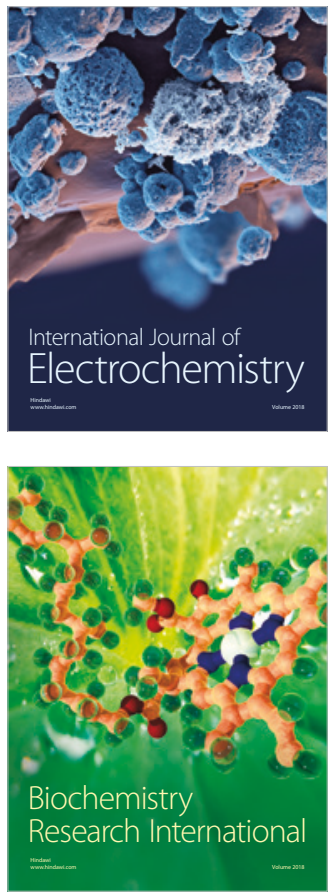